\title{
Latex constituents from Calotropis procera (R. Br.) display toxicity upon egg hatching and larvae of Aedes aegypti (Linn.)
}

\author{
Márcio Viana Ramos $/^{+}$, Glaís de Paiva Bandeira, Cléverson Diniz Teixeira de Freitas, \\ Nádia Accioly Pinto Nogueira*, Nylane Maria Nunes Alencar**, \\ Petrônio Augusto Simão de Sousa****, Ana Fontenele Urano Carvalho***/+
}

\begin{abstract}
Departamento de Bioquímica e Biologia Molecular *Departamento de Análises Clínicas e Toxicológicas **Departamento de Fisiologia e Farmacologia ***Departamento de Biologia, Universidade Federal do Ceará, Campus do Pici, 60451-970 Fortaleza, CE, Brasil ****Universidade Estadual do Ceará, Fortaleza, CE, Brasil
\end{abstract}

Calotropis procera $R$. Br. (Asclepiadaceae) is a well-known medicinal plant with leaves, roots, and bark being exploited by popular medicine to fight many human and animal diseases. This work deals with the fractionation of the crude latex produced by the green parts of the plant and aims to evaluate its toxic effects upon egg hatching and larval development of Aedes aegypti. The whole latex was shown to cause 100\% mortality of 3 rd instars within 5 min. It was fractionated into water-soluble dialyzable $(D F)$ and non-dialyzable (NDF) rubber-free materials. Both fractions were partially effective to prevent egg hatching and most of individuals growing under experimental conditions died before reaching 2nd instars or stayed in 1st instars. Besides, the fractions were very toxic to 3rd instars causing 100\% mortality within $24 \mathrm{~h}$. When both fractions were submitted to heat-treatment the toxic effects were diminished considerably suggesting low thermostability of the toxic compounds. Polyacrylamide gel electrophoresis of both fractions and their newly fractionated peaks obtained through ion exchange chromatography or desalting attested the presence of proteins in both materials. When submitted to protease digestion prior to larvicidal assays NDF lost most of its toxicity but DF was still strongly active. It may be possible that the highly toxic effects of the whole latex from $\mathrm{C}$. procera upon egg hatching and larvae development should be at least in part due to its protein content found in NDF. However the toxicity seems also to involve non protein molecules present in DF.

Key words: dengue - larvicidal - laticiferous plants - plant proteins - tropical diseases

Many tropical diseases persist in areas deserving investment in sanitation, appropriate treatment, and access to clean water. This is currently the case of many developing regions in Africa and Latin America, mainly in Northeastern Brazil (Hillyer \& Christensen 2002). Commonly mosquitoes proliferate abundantly in these areas as well as in natural areas like the Amazon Region. They act as vector of endemic diseases such as yellow fever in the Amazon Region and dengue hemorrhagic fever in many regions of Americas, South East Asia, the Pacific islands area, and Africa (Maillard et al. 1993). The mosquito Aedes aegypti Linn. (Diptera, Culicidae), the vehicle of transmission of theses infirmities, can be found disseminated everywhere within these areas and this contributes to aggravate the morbidity statistics. As attempts to control the drastic effects on public health the strategies include massive dissemination of expensive commercial pesticides into air and personal training visiting people in loci, which in turn is time-consuming. These strategies demand governmental support, which is usually limited in poor countries. In addition, Brazilian Ae. aegypti populations are highly resistant to insecticides used to control them (Da

Financial support: CNPq, MCT/PADCT, Funcap, IFS +Corresponding authors: aurano@ufc.br and vramos@ufc.br Received 4 November 2005

Accepted 30 May 2006
Cunha et al. 2005). Thus, It would be of great relevance to search for alternatives to improve the effectiveness of combating and preventing the proliferation of Ae. aegypti as well as other important mosquitoes involved in disease transmission to people and animal. Many sources of natural compounds have been suggested as alternatives for conventional chemical control (Consoli \& Oliveira 1994, Carvalho et al. 2003).

Calotropis procera $\mathrm{R}$. Br. (Asclepiadaceae) is a plant widely distributed in Asia, Africa, and Northeast of Brazil. The plant is popularly known because it produces large quantity of latex, which is easily collected from its green parts when the plant is wounded. The aspect of this natural secretion resembles that of rubber tree Hevea brasiliensis (Willd.ex Adr.Juss.) Müll.Arg. (Euphor-biaceae). Local people use it successfully to combat some skin fungi infections. The abundance of latex in the green parts of the plant reinforces the idea that it is produced and accumulated as a defense strategy against organisms such as virus, fungi, and insects (Larhsini et al. 1997, Haque et al. 2000) although it is possible to find wounded plants of Calotropis or to see insects visiting their leaves. When injured, leaves or the nearest other green parts exude the latex secretion which has a clingy effect capable of immobilizing insects. Additionally, the presence of plant defense-related proteins such as hevein, alpha-amylase inhibitor, among others, has been described to occur in the latex secretion of other plants (Wititsuwannakul et al. 1998, Pereira et al. 1999) and this seems to be also the case of Calotropis latex (Dubey \& Jagannadham 2003). Scien- 
tific descriptions have mentioned other relevant activities for the latex of $C$. procera, such as antibacterial, analgesic or possessing in vitro schizonticidal activity, among others (Jain et al. 1996, Dewan et al. 2000, Sharma \& Sharma 2000 , Alencar et al. 2004). In early 1980s a brief communication pointed out the whole latex of C. procera as a suitable source of active compounds exhibiting larvicidal activity (Girdhar et al. 1984). We have now extended this result reporting the effect of different rubber-free fractions of the latex upon egg hatching and larval development of the mosquito Ae. aegypti.

\section{MATERIALS AND METHODS}

Latex samples - Samples of C. procera were collected in Fortaleza, state of Ceará, Brazil. The voucher (sample specimen No. 32663) was deposited in Prisco Bezerra Herbarium of the Universidade Federal do Ceará (UFC), Brazil and the plant was authenticated by the taxonomist Edson Paula Nunes, Department of Biology, UFC. The plant occurs throughout the region of state of Ceará and it is exploited by local people mainly to combat fungi skin infection by applying its latex upon the infection site.

Fresh latex was collected from healthy plants by small incisions near the youngest leaves and left to flow off into distilled water in order to obtain a mixture 1:1 (v/v). The mixture was gently handled to maintain homogeneity during transport to the laboratory. It should be emphasized that the process of latex sampling does not compromise the health of plants. As a matter of fact they regenerate very fast. Samples were centrifuged $(5000 \mathrm{~g})$ at room temperature $\left(25^{\circ} \mathrm{C}\right)$ in a non-refrigerated bench top centrifuge for $10 \mathrm{~min}$. The precipitated material, showing rubber aspect, was pooled apart while the supernatant was submitted to exhaustive dialysis (cut off $8000 \mathrm{Da}$ ) against distilled water at $25^{\circ} \mathrm{C}$ and submitted to centrifugation as aforementioned. The new supernatant, devoid of rubber, was freeze-dried. This fraction was named non-dialyzable fraction (NDF). The dialyzable fraction (DF) was obtained after the first hour of dialysis when the supernatant was initially submitted to dialysis using a proportion of $1: 1$ sample:distilled water. Thus, the DF corresponded to the water used in the first $h$ of dialysis done immediately after the first centrifugation step. All experiments with the DF were performed with both fresh preparations or lyophilized material.

Egg hatching and larval development - Eggs of Ae. aegypti were obtained from Nuend - Núcleo de Endemias Transmissíveis por Vetores, Secretaria de Saúde, Ceará (Brazil). The eggs, deposited on paper strips were submerged into tap or distilled water and allowed to develop until reach the third larval stage at room temperature. About $20 \mathrm{mg}$ of soybean seed flour were added in water as nutrients source. In experiments designed to test the effects of both latex fractions upon egg hatching, paper strips of 1 $\mathrm{cm}^{2}$ were examined with the aid of an ordinary stereo microscope to count the number of eggs and were subsequently submerged directly into each sample tested.

Effect of NDF and DF upon egg hatching - Eggs of Ae. aegypti adsorbed on paper strips $\left(1 \mathrm{~cm}^{2}\right)$ were counted with the aid of an ordinary stereo microscope and placed in test tubes containing $3 \mathrm{ml}$ of each sample in triplicate. The lyophilized NDF fraction was dissolved in distilled water to give $200 \mu \mathrm{g} / \mathrm{ml}$. The DF was prepared just before use after dialysis as described before or lyophilized as desired. Bovine serum albumin (BSA) was used as control at the same concentration of the highest NDF dose (5 $\mathrm{mg} / \mathrm{ml}$ ). All the samples were diluted at different concentrations in distilled water and egg hatching was monitored for 24,48 , and $72 \mathrm{~h}$. Distilled water without protein was also used as control. Likewise, the effect of heat treatment upon the NDF and DF fractions was determined after heating the fractions at $100^{\circ} \mathrm{C}$ for different periods of time. Egg hatching rate was monitored for 24,48 , and $72 \mathrm{~h}$. The assays were developed at $25^{\circ} \mathrm{C}$.

Evaluation of toxicity of the crude latex and effect of $N D F$ and DF upon the 3rd instar larvae - Crude latex of C. procera was collected in distilled water as described above and serial dilutions (up to 1:10,000) were prepared in order to obtain decreasing concentrations of its toxic compounds. Ten 3 rd instars were added to glass tubes (20 $\mathrm{mm} \times 100 \mathrm{~mm}$ ) containing $5 \mathrm{ml}$ of each dilution in triplicate. Larvae behavior was followed for $24 \mathrm{~h}$ at $25^{\circ} \mathrm{C}$.

The NDF lyophilized fraction at the concentration of $10 \mathrm{mg} / \mathrm{ml}$ in distilled water was diluted in test tubes to give serial dilutions of 1:2,1:10, 1:50,1:100, and 1:500. Ten 3 rd instar larvae were added to each tube and their development monitored for $48 \mathrm{~h}$. Experiments were carried out at $25^{\circ} \mathrm{C}$ in triplicates with 10 individuals in each tube containing $5 \mathrm{ml}$ solution.

The DF and its dilutions in distilled water were prepared in glass tubes $(5 \mathrm{ml})$, in triplicate. Ten 3rd instars were placed into each test tube and larval survival observed for $24 \mathrm{~h}$. All results were expressed as percent mortality after 1,3 , and $24 \mathrm{~h}$ of exposure.

As an attempt to evidence the nature of substances causing larvae mortality, both NDF and DF fractions were submitted to heat treatment as before and thus assayed as described above. Results were expressed as percent mortality. Last, both NDF and DF were submitted to enzymatic action using protease from Streptomyces griseus (SIGMA P-5147) during $24 \mathrm{~h}$ at $37^{\circ} \mathrm{C}$ in $100 \mathrm{mM}$ PBS pH 7.4. The enzyme was added three times at an enzymesample ratio of $1: 100(\mathrm{w}: \mathrm{w})$ at zero, 12 , and $18 \mathrm{~h}$ of digestion. After digestion samples were heated at $60^{\circ} \mathrm{C}$ for 10 $\min$ to inactivate the enzyme. The samples were thus diluted to a final volume of $200 \mathrm{ml}$ in distilled water containing $1 \%$ ethanol and four replicates of $1000 \mu \mathrm{g} / \mathrm{ml}$ (NDF) and $5000 \mu \mathrm{g} / \mathrm{ml}$ (DF) were prepared each receiving 50 3rd instars. Controls were done with enzyme in water and water both containing $1 \%$ ethanol. The assays were performed in $400 \mathrm{ml}$ glass cups that were stored in a growth chamber with temperature $\left(25^{\circ} \mathrm{C}\right)$ and dark/light cycle $(12: 12 \mathrm{~h})$ controlled and observed for $24 \mathrm{~h}$. Results were expressed as mean of percentage of mortality observed.

Toxic effects of NDF and DF on mice - The use of mice for toxicity assays was conducted in accordance with the internationally accepted principles for laboratory animal use and care as found in the European Community guidelines (EEC Directive of 1986; 86/609/EEC). The acute toxicity was verified according to Miller and Tainter (1944) 
by intravenous injection of the NDF saline solutions at 3, $10,30,100$, and $300 \mathrm{mg} \cdot \mathrm{kg}^{-1}$ body weight. The toxicity of dialysis water (DF) containing low molecular mass compounds was tested according to Litchfield and Wilcoxon (1949) by i.p. injection at $78 \mathrm{mg} \cdot \mathrm{kg}^{-1}$ to $1250 \mathrm{mg} \cdot \mathrm{kg}^{-1}$. Groups of six animals ( 3 male and 3 females each) were handled apart in cages with free access to drinking water and food and maintained in the laboratory at $25^{\circ} \mathrm{C}$. The animals were observed as to changes in behaviour and in physiological patterns of defecation and miction during $48 \mathrm{~h}$.

Ion exchange chromatography on CM-cellulose column - The NDF fraction was submitted to ion exchange chromatography on a CM-cellulose column previously equilibrated with $50 \mathrm{mM}$ acetate-Na buffer $\mathrm{pH}$ 5.0. Samples of $30 \mathrm{mg}$ into $3 \mathrm{ml}$ were assayed. After washing the column with acetate buffer to elute the unbound proteins, the column was eluted with $0.2 \mathrm{M}$ and $0.3 \mathrm{M} \mathrm{NaCl}$ sequentially. Three distinct protein peaks named PI (unbound), PII, and PIII were thus recovered, dialyzed against distilled water and lyophilized. They were further checked by PAGE-SDS and tested for toxicity.

HPLC and desalting chromatography - The DF fraction, expected to be composed of low molecular mass compounds was passed through a Superdex Peptide HR 10/30 column in $1 \%$ TFA $/ 25 \%$ acetonitrile. Four peaks were recovered and further analyzed to determine amino acid composition as cited in Ramos et al. (1998). After that, DF fraction was submitted to a desalting step using a PD-10 column (G\&E healthcare) and the peak corresponding to peptides was further analyzed by SDS-PAGE and for larval toxicity.

Polyacrylamide gel electrophoresis - The mixture of proteins in the NDF and the DF obtained by fractionation of the latex as well desalting peaks of DF obtained after PD-10 chromatography were examined in 12.5 and $17 \%$ polyacrylamide gel electrophoresis, at the presence of sodium dodecyl sulfate (SDS) according to Laemmli (1970) and Schagger and Jagow (1987), respectively. Samples were treated with Tris-HCl buffer, $\mathrm{pH} 6.8$ containing $2 \%$ SDS and $5 \% \beta$-mercaptoethanol at $100^{\circ} \mathrm{C}$ for $4 \mathrm{~min}$ and applied into the gel. Runs were performed at $40 \mathrm{~mA}$ at $25^{\circ} \mathrm{C}$. Gels were stained with coomassie brilliant blue so- lution in water: acetic acid: methanol (8:1:3.5) and distained with the same solution without the dye. Molecular mass markers were from Sigma Chemical Company (US).

Protein content - The protein content of both DF and NDF was estimated by the colorimetric method of Coomassie Brilliant Blue according to Bradford (1976) using BSA as standard.

\section{RESULTS}

The results showed that the crude latex of $C$. procera collected into distilled water $1: 1(\mathrm{v} / \mathrm{v})$ caused $100 \%$ mortality of 3rd instars within $5 \mathrm{~min}$ and the toxic effects were still observed after $24 \mathrm{~h}$ at dilutions as high as 1: 1000 . This material was thus further fractionated and the corresponding fractions analyzed separately.

The NDF of the latex was ineffective in preventing egg hatching at lower doses. As a matter of fact, egg hatching in bovine serum albumin and latex proteins at $200 \mu \mathrm{g} / \mathrm{ml}$ in water was comparable to that hatching in water (Table I). As a rule, egg hatching was slightly greater in NDF at $200 \mu \mathrm{g} / \mathrm{ml}$ if compared to the controls. However, the larvae growing either in BSA or in water were apparently healthier than those growing in NDF which were less active. Besides, there was an expressive larvae mortality reaching 2nd instars in NDF throughout the assay. Although the NDF fraction did not cause $100 \%$ mortality of $2 \mathrm{nd}$ instars when assayed at $200 \mu \mathrm{g} / \mathrm{ml}$, the survivors did not cope to attain 3rd instars level within $72 \mathrm{~h}$ differing from what usually happened to control groups. Egg hatching was fully inhibited when NDF was tested at 10 $\mathrm{mg} / \mathrm{ml}$ (Table I).

The efficiency of the NDF as larvicidal was also proven when the fraction was tested against 3rd instars (Table II). Doses of $1000 \mu \mathrm{g} / \mathrm{ml}$ caused $100 \%$ mortality within 24 $\mathrm{h}$ with $83.3 \%$ of mortality occurring within the first $3 \mathrm{~h}$. The protein content of this fraction determined after dialysis and prior to lyophilization was estimated as $5.2 \mathrm{mg} /$ $\mathrm{ml}$ according to method of Bradford (1976). Analysis of this fraction by $12.5 \%$ polyacrylamide gel electrophoresis confirmed the presence of many proteins with apparent molecular mass ranging from 10,000 to 95,000 Da, with three major protein bands lower than 30,000 Da. (Fig. 1).

TABLE I

Effects of latex dialyzed (DF) and non-dialyzed (NDF) fractions on eggs hatching of Aedes aegypti

\begin{tabular}{|c|c|c|c|c|c|}
\hline Samples & Number of eggs & $\%$ hatching & $\begin{array}{l}\text { Number of } \\
\text { live larvae }\end{array}$ & $\begin{array}{l}\text { Number of } \\
\text { dead larvae }\end{array}$ & $\%$ mortality \\
\hline Water & 88 & 40.90 & 46 & 0 & 0 \\
\hline Control (BSA) & 90 & 30 & 27 & 0 & 0 \\
\hline $\mathrm{NDF}-200 \mu \mathrm{g} / \mathrm{ml}$ & 146 & 53.42 & 23 & 55 & 70.51 \\
\hline $\mathrm{NDF}-1 \mathrm{mg} / \mathrm{ml}$ & 152 & 44.07 & 23 & 44 & 65.67 \\
\hline $\mathrm{NDF}-10 \mathrm{mg} / \mathrm{ml}$ & 157 & 0 & - & - & - \\
\hline $\mathrm{DF}-1 \mathrm{mg} / \mathrm{ml}$ & 123 & 37.39 & 46 & 0 & 0 \\
\hline $\mathrm{DF}-10 \mathrm{mg} / \mathrm{ml}$ & 147 & 35.37 & 27 & 25 & 48.07 \\
\hline $\mathrm{DF}-50 \mathrm{mg} / \mathrm{ml}$ & 149 & 0 & - & - & - \\
\hline $\mathrm{DF}-100 \mathrm{mg} / \mathrm{ml}$ & 138 & 0 & - & - & - \\
\hline
\end{tabular}

Bovine serum albumin (BSA) was assayed at $10 \mathrm{mg} / \mathrm{ml}$. Number of live larvae corresponds to the individuals still alive at the final time of observation. Results were recovered after $72 \mathrm{~h}$. 
Thus, it is reasonable to consider that the protein fraction ought to be involved in the larvicidal activity. To evidence facts to support this hypothesis, the NDF was heattreated prior to exposure to the 3rd instars. As shown in Table III, doses corresponding to $200 \mu \mathrm{g} / \mathrm{ml}$ had its toxic activity strongly diminished after $15 \mathrm{~min}$ of heating, reinforcing the hypothesis that the latex proteins would be, at

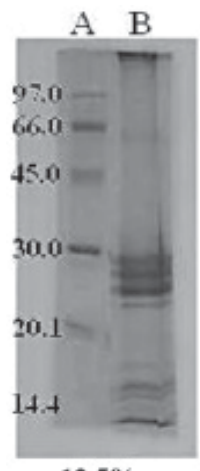

$12.5 \%$

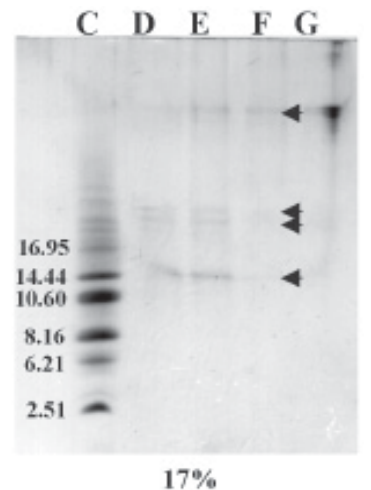

$17 \%$
Fig. 1: electrophoretic profiles of the non-dialyzable (NDF) and dialyzable (DF) fractions of Calotropis procera latex. A: molecular mass markers (Phosphorylase B, 97.0 KDa, Bovine serum albumin, 66.0 KDa, Ovalbumin, $45 \mathrm{KDa}$, Carbonic anhydrase, $30 \mathrm{KDa}$, Trypsin inhibitor, $20.1 \mathrm{KDa}$, alpha-lactalbumin, 14.4 KDa); B: $\mathrm{NDF}$ of the latex from $C$. procera; C: molecular mass markers (Myoglobin 16.950, Myoglobin I+II 14.44 KDa, Myoglobin I+III $10.60 \mathrm{KDa}$, Myoglobin I 8.16 KDa, Myoglobin II 6.21 KDa, Glucagon $3.46 \mathrm{KDa}$, Myoglobin III 2.51 KDa); D and E: DF; F and G: PI from PD-10 desalting column which exhibits low toxicity against 3rd instars.

\section{TABLE II}

Larvicidal activity of the non-dialyzable fraction (NDF) and dialyzable fraction (DF) of Calotropis procera latex against 3rd instars of Aedes aegypti after different exposure time

\begin{tabular}{lccc}
\hline $\begin{array}{l}\text { Concentration } \\
\mu \mathrm{g} / \mathrm{ml})\end{array}$ & \multicolumn{3}{c}{$\%$ mortality ${ }^{a}$} \\
\cline { 2 - 4 } NDF & $1 \mathrm{~h}$ & $3 \mathrm{~h}$ & $24 \mathrm{~h}$ \\
\hline 20 & $0.0 \pm 0.0$ & $0.0 \pm 0.0$ & $0.0 \pm 0.0$ \\
100 & $0.0 \pm 0.0$ & $0.0 \pm 0.0$ & $56.6 \pm 8.16$ \\
200 & $0.0 \pm 0.0$ & $0.0 \pm 0.0$ & $86.6 \pm 9.4$ \\
1000 & $33.3 \pm 16.9$ & $83.3 \pm 9.4$ & $100.0 \pm 0.0$ \\
5000 & $90.0 \pm 8.7$ & $100.0 \pm 0.0$ & $100.0 \pm 0.0$ \\
BSA & $0.0 \pm 0.0$ & $0.0 \pm 0.0$ & $0.0 \pm 0.0$ \\
\hline Water & $0.0 \pm 0.0$ & $0.0 \pm 0.0$ & $0.0 \pm 0.0$ \\
DF & $1 \mathrm{~h}$ & $3 \mathrm{~h}$ & $24 \mathrm{~h}$ \\
Water & $0.0 \pm 0.0$ & $0.0 \pm 0.0$ & $0.0 \pm 0.0$ \\
BSA & $0.0 \pm 0.0$ & $0.0 \pm 0.0$ & $0.0 \pm 0.0$ \\
Non-diluted & $63.3 \pm 4.7$ & $90.0 \pm 14.1$ & $100.0 \pm 0.0$ \\
DF $(\mu \mathrm{g} / \mathrm{ml})$ & $1 \mathrm{~h}$ & $3 \mathrm{~h}$ & $24 \mathrm{~h}$ \\
\hline 20 & $0.0 \pm 0.0$ & $0.0 \pm 0.0$ & $0.0 \pm 0.0$ \\
100 & $0.0 \pm 0.0$ & $0.0 \pm 0.0$ & $0.0 \pm 0.0$ \\
200 & $0.0 \pm 0.0$ & $0.0 \pm 0.0$ & $0.0 \pm 0.0$ \\
1000 & $20.0 \pm 10.0$ & $23.3 \pm 5.7$ & $50.0 \pm 17.3$ \\
5000 & $63.3 \pm 5.7$ & $76.6 \pm 5.7$ & $100.0 \pm 0.0$ \\
10000 & $76.6 \pm 11.54$ & $86.6 \pm 15.2$ & $100.0 \pm 0.0$ \\
\hline
\end{tabular}

$a$ : values are means of three replicates and standard deviation. Bovine serum albumin (BSA) was assayed at $10 \mathrm{mg} / \mathrm{ml}$. least in part, responsible for the deleterious effects observed upon larval development. The NDF was thus fractionated by ion-exchange chromatography (Fig. 2). A nonretained fraction (PI) and two peaks that were eluted under increasing salt concentration (PII and PIII) were examined for larvicidal activity after dialysis and lyophilization. There was no toxic effect towards 3rd instars in assays with PI and PII. Toxic activity was found to be present in the fraction corresponding to PIII (Table IV). However it was weaker than that found with NDF when assayed at the same concentration $(200 \mu \mathrm{g} / \mathrm{ml})$. Besides, the toxicity of PIII was observed only after $48 \mathrm{~h}$ while effects of NDF were clearly observed after $24 \mathrm{~h}$. This data deserves further investigation since it would be expected a more potent activity in a more purified fraction. In addition, electrophoretic analysis of PIII showed the presence of protein bands and this result again points out to the protein nature of the larvicidal compounds present in NDF. As a last attempt to determine the involvement of proteins in the larval toxicity, NDF was submitted to digestion by a broad specificity protease. After $24 \mathrm{~h}$ under digestion,

\section{TABLE III}

Larvicidal activity of heat-treated non-dialyzable fraction (NDF) and dialyzed fraction (DF) of Calotropis procera latex against 3rd instars of Aedes aegypti

\begin{tabular}{lcc}
\hline \multirow{2}{*}{$\begin{array}{l}\text { Time of } \\
\text { heat-treatment } \\
\text { at } 100^{\circ} \mathrm{C}(\mathrm{min})\end{array}$} & \multicolumn{2}{c}{ Percent mortality after $24 \mathrm{~h}^{a}$} \\
\cline { 2 - 3 } & $\mathrm{NDF}(200 \mu \mathrm{g} / \mathrm{ml})$ & $\mathrm{DF}(5 \mu \mathrm{g} / \mathrm{ml})$ \\
\hline 0 & $86.7 \pm 4.7$ & $70.0 \pm 26.45$ \\
15 & $20.0 \pm 14.1$ & $63.3 \pm 15.27$ \\
30 & $26.7 \pm 9.2$ & $53.3 \pm 10.0$ \\
45 & $3.7 \pm 4.7$ & $0.0 \pm 10.0$ \\
60 & $13.4 \pm 4.7$ & $23.3 \pm 15.27$ \\
Control (water) & $0.0 \pm 0.0$ & $0.0 \pm 0.0$ \\
\hline
\end{tabular}

$a$ : values are means of three replicates and standard deviation.

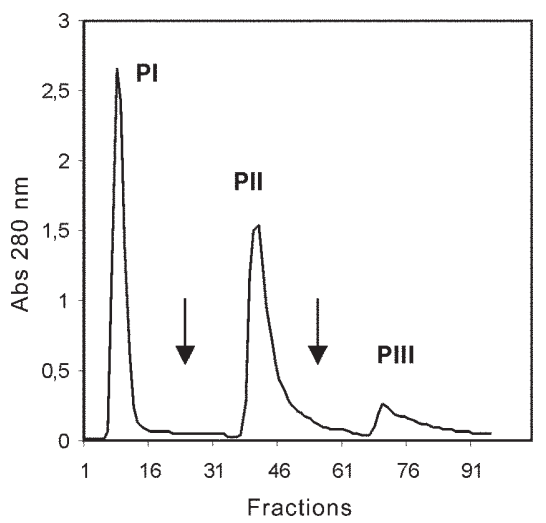

Fig. 2: chromatography of non-dialyzable fraction (NDF) of Calotropis procera latex on CM-Sepharose column. NDF (10 mg/ $\mathrm{ml}$ ) was applied to a CM-Sepharose fast flow column equilibrated with $0.05 \mathrm{M}$ acetate buffer, $\mathrm{pH} 5.0$ and washed extensively with the same buffer. The arrows indicate the elution of the bound proteins with $0.05 \mathrm{M}$ acetate buffer, $\mathrm{pH} 5.0$ containing $0.2 \mathrm{M}$ and $0.3 \mathrm{M}$ $\mathrm{NaCl}$ respectively. The fractions of $2 \mathrm{ml}$ were collected at a flow rate of $1 \mathrm{ml} / \mathrm{min}$ and assayed for protein content at $280 \mathrm{~nm}$. PIII was shown to still exhibit toxicity against 3rd instars. 
TABLE IV

Larvicidal activity of the non-dialyzable fraction (NDF) and dialyzable fraction (DF) of Calotropis procera latex against 3rd instars of Aedes aegypti after chromatography ${ }^{a}$

\begin{tabular}{lcccr}
\hline Fraction & \multicolumn{3}{c}{$\%$ mortality } \\
\cline { 2 - 5 } NDF $(200 \mu \mathrm{g} / \mathrm{ml})$ & $1 \mathrm{~h}$ & $3 \mathrm{~h}$ & $24 \mathrm{~h}$ & $48 \mathrm{~h}$ \\
\hline PI CM-Sepharose & $0.0 \pm 0.0$ & $0.0 \pm 0.0$ & $0.0 \pm 0.0$ & $0.0 \pm 0.0$ \\
PII CM-Sepharose & $0.0 \pm 0.0$ & $0.0 \pm 0.0$ & $0.0 \pm 0.0$ & $0.0 \pm 0.0$ \\
PIII CM-Sepharose & $0.0 \pm 0.0$ & $0.0 \pm 0.0$ & $0.0 \pm 0.0$ & $0.0 \pm 0.0$ \\
BSA & $0.0 \pm 0.0$ & $0.0 \pm 0.0$ & $0.0 \pm 0.0$ & $0.0 \pm 0.0$ \\
Water & $0.0 \pm 0.0$ & $0.0 \pm 0.0$ & $24 \mathrm{~h}$ & $0.0 \pm 0.0$ \\
DF $(10 \mathrm{mg} / \mathrm{ml})$ & $1 \mathrm{~h}$ & $3 \mathrm{~h}$ & $48 \mathrm{~h}$ \\
\hline PI PD-10 & $0.0 \pm 0.0$ & $0.0 \pm 0.0$ & $37.77 \pm 0.7$ & ND \\
PII PD-10 & $16.49 \pm 0.0$ & $23.53 \pm 0.0$ & $83.86 \pm 9.66$ & ND
\end{tabular}

$a$ : the assays were done as described in materials and methods in triplicate with thirty individuals separated in tubes containing $5 \mathrm{ml}$ of samples. ND: not determined.

NDF was assayed for larval toxicity. Digests of NDF caused $23.9 \%$ of mortality while NDF non digested killed $97.49 \%$ of 3 rd instars. This result agrees with the others reported above which suggest participation of proteins present in NDF in larval toxicity. No death was observed in the controls with or without the enzyme.

The latex submitted to dialysis against water gave rise to a very clean DF that presented a maximum absorbance at $280 \mathrm{~nm}$ although a negligible concentration of protein was detected by the Bradford assay. This fraction corresponding to the water used at the first $\mathrm{h}$ of dialysis was tested to determine its toxic effect upon eggs hatching and 3rd instars. When challenged to hatch at the presence of DF, eggs of Ae. aegypti seemed to produce healthy 1st instars similar to those of BSA and water controls within the first $24 \mathrm{~h}$. Later on, larvae mortality was observed only at $10 \mathrm{mg} / \mathrm{ml}$, a trend observed until $72 \mathrm{~h}$. Live individuals were markedly less active when compared to those from control groups and could not reach 2 nd instars level. Higher doses of DF drastically affected eggs hatching (Table I).

Notably, this fraction displayed considerable toxic effects upon 3rd instars (Table II). However, it was effective at doses higher than those used for egg hatching assay. It should be mentioned that this fraction must be rich in water soluble small molecules (ions, salts and secondary metabolites) as it was fractionated by molecular size exclusion (dialysis). Attempts to characterize this fraction for protein/peptide content included a desalting step and molecular sieving chromatography on HPLC (Fig. 3). Profile of DF and the peak recovered after desalting analyzed by electrophoresis is shown in Fig. 1. Apparently four distinct peptides could be identified in the whole DF sample and a single (more evident) protein band was recovered after passage through the PD-10 column corresponding to PI (Fig. 3). Accordingly, PI from PD 10 exhibited a single peak in Superdex peptide column (Fig. 3 B). This PD-10 fraction still exhibited toxicity towards 3rd instars suggesting the involvement of peptides in toxic activity of NDF (see Table IV). However toxic activity was also found in the PII of PD-10. Since most toxic activity of DF was found in this fraction (PII) it is expected that other molecules with molecular mass lower than 5000 Da probably of non protein nature are also involved in larval toxicity (Table IV). Amino acid composition determined in four peaks of DF fractionated by Superdex peptide indicated the presence of peptides within the sample (Table V). It should be mentioned that amino acid analysis of peaks without previous digestion by $\mathrm{HCl}$ gave negligible contents of amino acid suggesting low concentration of free amino acids in DF. It must be noted that proteins from DF which were recovered from dialysis water must exhibit molecular masses lower than 8000 , the exclusion limit of the dialysis membrane used. Although results from PD-10 and superdex peptide corroborate with this data, electrophoresis pattern of DF does not. Repeatedly, proteins bands of DF migrate anomalously in SDS-PAGE appearing as proteins with molecular size higher than they actually have. Electrophoresis of this material ran on $12.5 \%$ polyacrylamide gels does not exhibit protein bands that suggest the proteins in DF do not have correspondents in NDF. Thus it should not be contaminated by NDF material.

Similar to NDF, DF lost its toxicity to 3rd instars when heated at $100^{\circ} \mathrm{C}$ (Table III). DF was also submitted to protease digestion as described to NDF. Digested material of DF $(5 \mathrm{mg} / \mathrm{ml})$ was thus assayed for larval activity. After 24 h digests of DF caused $77.49 \%$ of mortality while non digested DF killed 100\% of 3rd instars. This result does not give new insights to suggest participation of proteins (peptides) of DF in larval toxicity.

The results of acute toxicity tests with mice showed that intravenous injections of NDF did not cause any adverse effects or mortality at concentrations corresponding to that exhibiting larvicidal activity. $\mathrm{A} \mathrm{LD}_{50}$ of $25.8 \pm$ $4.2 \mathrm{mg} \cdot \mathrm{kg}^{-1}$ was found. This dose is far higher then that proved to be necessary to eliminate 3 rd instars. Thus as a preliminary observation NDF would not exhibit toxicity against mammals at doses known to kill larvae. When intravenously injected at 3 and $10 \mathrm{mg} \cdot \mathrm{kg}^{-1}$ the NDF caused a slight sedation in the animals whereas at doses of 30 , 100 , and $300 \mathrm{mg} \cdot \mathrm{kg}^{-1}$ caused strong respiratory sedation, 
A

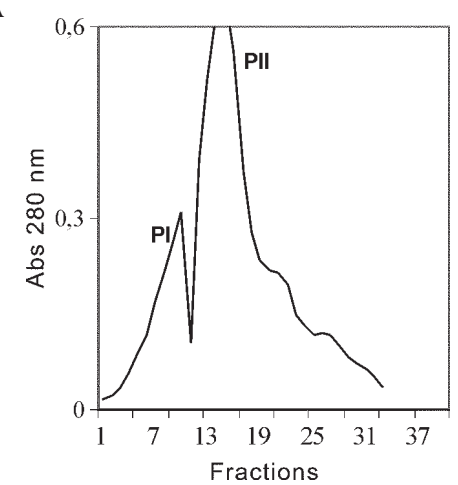

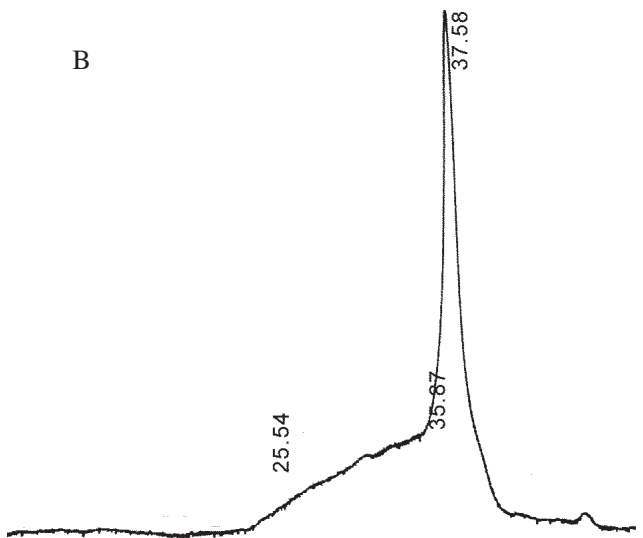

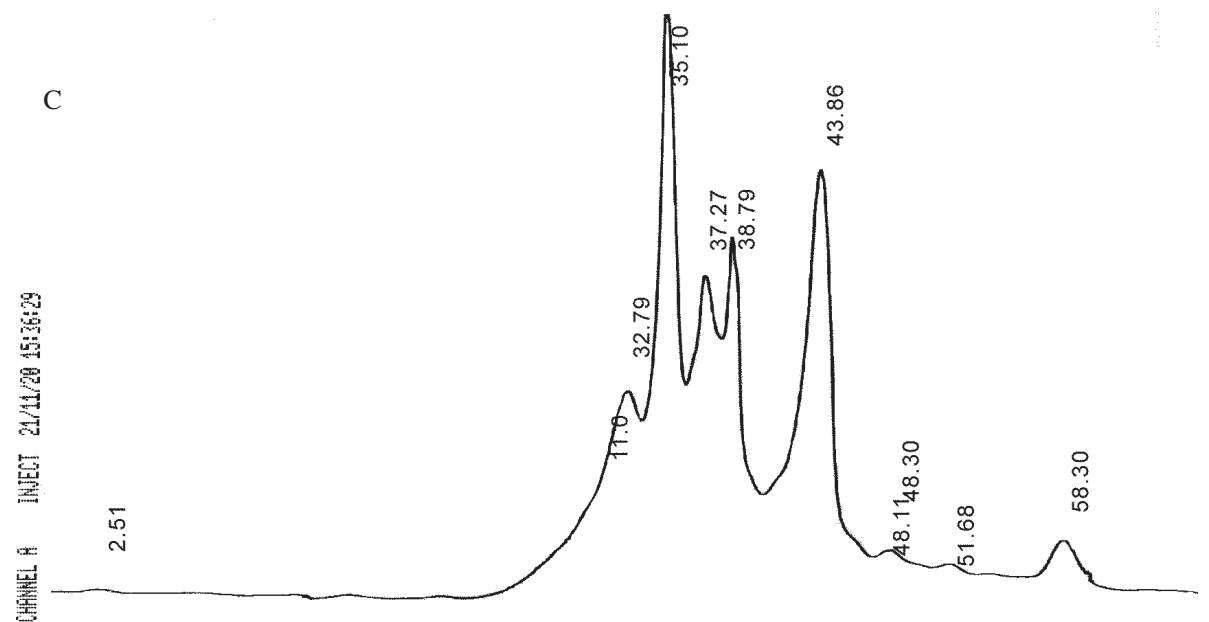

Fig. 3-A: chromatography of dialyzable fraction (DF) $(25 \mathrm{mg}$ ) of Calotropis procera latex on PD-10 desalting column; B: chromatography of PI $(20 \mathrm{mg} / \mathrm{ml})$ from PD-10 in Superdex peptide; C: DF $(500 \mathrm{mg} / \mathrm{ml})$ in Superdex peptide. The samples were prepared as described in methods.

\section{TABLE V}

Amino acid composition of Peaks from dialyzable fraction after passage through Superdex peptide column

\begin{tabular}{lcccc}
\hline Amino acid residues & \multicolumn{4}{c}{ Mol \% } \\
\hline & PI & PII & PIII & PIV \\
Asparagine/Aspartic acid & 3.42 & ND & ND & ND \\
Glutamine/Glutamic acid & 7.57 & 4.39 & ND & ND \\
Serine & 5.41 & 3.14 & 3.44 & 7.88 \\
Glycine & 19.33 & 13.46 & 7.38 & 16.89 \\
Histidine & 3.99 & 4.63 & ND & ND \\
Arginine & 4.48 & ND & ND & ND \\
Threonine & 3.06 & 3.56 & 3.90 & 4.46 \\
Alanine & 6.88 & 5.32 & 5.83 & 3.34 \\
Proline & 11.85 & 34.41 & 30.18 & 47.50 \\
Tyrosine & ND & ND & 5.93 & ND \\
Valine & 9.04 & 7.00 & 11.51 & 8.78 \\
Methionine & ND & 4.45 & 4.88 & ND \\
Isoleucine & 6.75 & 11.75 & 8.59 & ND \\
Leucine & 10.13 & 7.83 & 12.89 & 4.91 \\
Phenylalanine & 4.25 & ND & 5.41 & 6.19 \\
Lysine & 3.76 & ND & ND & ND \\
\hline Total & 99.92 & 99.94 & 99.94 & 99.95
\end{tabular}

ND: not detected; tryptophan and cysteine were not analyzed. analgesia and coma. Concerning the DF, acute toxicity was carried out by intraperitoneal injection. $\mathrm{ALD}_{50}$ corresponding to $534 \pm 21.8 \mathrm{mg} \cdot \mathrm{kg}^{-1}$ was determined. DF was larvicidal at doses as low as $5000 \mu \mathrm{g} / \mathrm{ml}$ (Table II).

\section{DISCUSSION}

The latex of $C$. procera is milky and resembles the well-characterized latex from Hevea brasiliensis (rubber tree). The rubber fraction was successfully separated from the water-soluble material by a single step of dialysis against distilled water. Both water-soluble fractions (NDF and DF) separated by a dialysis membrane (cut off 8000 ) seem to be toxic against eggs hatch and larvae of $A e$. aegypti. First of all, it should be emphasized that the most potent larvicidal action was achieved with the whole latex. Hence it is reasonable to consider that rubber fraction shows harmful effects upon larvae. Indeed, assays performed using the rubber fraction instead of the soluble fractions caused larval death in a few min. However, the low water solubility of the rubber drastically diminishes its usefulness in mosquito control programs. Secondly, as aforementioned, the aim of the present investigation was to characterize different fractions of the latex under the perspective of identifying the chemical nature of its 
toxic substances and defining its potentiality for use in programs for fighting dengue mosquito proliferation. In fact, the shift from the regular pesticides (organophosphate) to plant extracts in controlling insect-vectors or pests in general, paves the way to a health environment. In this work, ovicidal activity was shown for the fractions (either NDF or DF), similar to what has been reported for the whole latex (Girdhar et al. 1984). Nevertheless, the emerged larvae apparently were less healthy than those of control treatment and unable to develop appropriately. Besides, both fractions showed toxic effects against 3rd instars. The results seem to implicate the participation of proteins (NDF) and peptides and possibly other low molecular mass compounds (DF) as responsible for the toxic effects upon Ae. aegypti larvae. NDF is rich in protein (52\%) as determined by the method of Bradford (1976) with pattern visualized by SDS polyacrylamide gel electrophoresis. Modified electrophoresis approach was successful in detecting proteins (peptides) in the DF. Accordingly, the presence of small peptides should not be discarded since DF showed maximum absorbance at 280 $\mathrm{nm}($ O.D. $=2300)$ and reduced larvicidal action after heat treatment. In addition, running of DF through a molecular exclusion chromatography column monitored by an HPLC system gave rise to four peaks which were further shown to contain amino acids after digestion. Both fractions (NDF and DF) were previously shown to be very poor in carbohydrates as determined according to Dubois et al. (1956) assay. It is noteworthy that the identities of larval-killingcompounds in laticiferous plants have not yet been determined but various researchers have undertaken the chemical analysis of $C$. procera latex and several compounds have been identified such as cardenolides, proteolytic enzymes, alkaloids and carbohydrates (Dhar \& Sungh 1973, Seiber et al. 1982, Morsy et al. 2001). It should be mentioned here that attempts were done to prove the involvement of molecules of protein nature in both NDF and DF in larval and egg hatching toxicity. Although evidences point out to the participation of NDF proteins in the toxicity, the same was not evident to DF. Most laticiferous plants have as the main latex constituent the rubber, a poly-isoprene structure that is well known to occur in the latex of $H$. brasiliensis tree. Nevertheless the latex in most plants is a complex mixture of biological compounds including free amino acids, secondary metabolites among others and free proteins in the sera and associated with latex organelles that can be separated by highspeed centrifugation (Yeang et al. 2002). It has been shown that different concentrations of $C$. procera latex were topically applied to 3rd stage larvae of Musca domestica L. (Diptera, Muscidae). A dose of $3 \mu 1$ (5\% of the latex) was able to kill and partially digest the larvae in $3 \mathrm{~h}$ suggesting that the larvicidal effect of this latex was most probably enzymatic in nature (Morsy et al. 2001). Thus it is possible that proteins with enzymatic nature might be also involved in the larvicidal activity of $C$. procera latex against Ae. aegyti. As a matter of fact, Dubey and Jagannadham (2003) described the purification of a protease from the latex of $C$. procera and the molecular mass of the enzyme was $28.8 \mathrm{kDa}$. In the present work proteins with apparent molecular mass ranging from 8000 to 95,000
Da were shown in the NDF, with three major protein bands appearing near 30,000 Da (Fig. 1). Modified electrophoresis as described by Schagger and Jagow (1987) allowed detection of small molecular mass peptides present in DF. Four peptides identified corroborated with four distinct peaks detected when DF was chromatographed on a Superdex Peptide HR 10/30 (Pharmacia Biotech). Amino acid analysis of such fractions confirmed the presence of distinct compositions, suggesting the presence of distinct peptides (Table V).

Although the toxicity assays of DF and NDF did not show strong acute effects on mice and the $\mathrm{LD}_{50}$ for the $\mathrm{DF}$ and NDF were somewhat high, i.e. much over $1 \mathrm{mg} . \mathrm{kg}^{-1}$ body weight, further studies on the safety of using NDF or any of the constituents of $C$. procera must be carried out considering that available data are still inconclusive. Some workers have considered the toxicity of latex moderate, and have described it as less hazardous as compared to insecticides like aldrin, although contact with eyes and skin should be avoided (Girdhar et al. 1984, Al Mezaine et al. 2005). Others, however, have made warnings about the contact dermatitis produced by $C$. procera, about the latex biogenic amines that produce intense inflammation when injected locally in rats (Shivkar \& Kumar 2003) and about the fact that the latex given to goats by different routes of administration caused death between 20 min and 4 days (el Badwi et al. 1998).

The present work aimed to fractionate the naturally occurring latex of $C$. procera getting rid of its rubber fraction and testing the effects of its water-soluble fraction upon larval development of the mosquito Ae. aegypti.

The latex of $C$. procera possesses a potent toxic activity against larvae of the yellow fever and dengue mosquito Ae. aegypti. The study gave a weight into the possibility of formulating suitable preparation from the water-soluble fractions (DF or NDF) of C. procera latex for use in mosquito control programs. Further advantage is that $C$. procera latex is available throughout the year and especially when the mosquito population is higher. The plants grow in nature without any additional care or cost and simple technology would be necessary to separate the most suitable fractions to be exploited as a possible chemical to be used in mosquito control programs. This work has also been encouraged by the recent findings described by Singhi and co-workers (2004) who have shown that the whole latex of $C$. procera provokes refractory effects on the ovipositioning behavior of Ae. aegypti (Singhi et al. 2004).

\section{REFERENCES}

Al Mezaine HS, Al Rajhi AA, Al-Assiri A, Wagoner MD 2005. Calotropis procera (ushaar) keratitis. Am J Ophtalmol 139: 199-202.

Alencar NMN, Figueiredo IST, Vale MR, Bitencourt FS, Oliveira JS, Ribeiro RA, Ramos MV 2004. Anti-inflammatory effect of the latex from Calotropis procera in three different experimental models: Peritonitis, paw edema and hemorrhagic cystitis. Planta Medica 70: 1144-1149.

Bradford MM 1976. A rapid and sensitive method for the quantification of microgram quantities of proteins utilizing the principle of protein-dye binding. Anal Chem 72: 248-254. 
Carvalho AFU, Melo VMM, Craveiro AA, Machado MIL, Bantim MB, Rabelo EF 2003. Larvicidal activity of the essential oil from Lippia sidoides Cham. against Aedes aegypti Linn. Mem Inst Oswaldo Cruz 98: 569-571.

Consoli RA, Oliveira RL 1994. Principais Mosquitos de Importância Sanitária no Brasil, Fiocruz, Rio de Janeiro, 225 pp.

Da Cunha MP, Lima JBP, Brogdon WG, Moya GE, Vale D 2005. Monitoring of resistance to the pyrethroid cypermethrin in Brazilian Aedes aegypti (Diptera: Culicidae) populations collected between 2001 and 2003. Mem Inst Oswaldo Cruz, 100: 199-203.

Dhar DN, Sungh RK 1973. The chemistry of Calotropis procera. The Eastern Pharmacist 176: 99-101.

Dewan S, Sangraula H, Kumar VL 2000. Preliminary studies on the analgesic activity of latex of Calotropis procera. $J$ Ethnopharmacol 73: 307-311.

Dubey VK, Jagannadham MV 2003. Procerain, a stable cysteine protease from the latex of Calotropis procera. Phytochemstry 62: 1057-1071.

Dubois M, Gilles KA, Hamilton JK 1956. Colorimetric method for determination of sugars and related substances. Anal Chem 28: 350-356.

EEC Directive of 1986. Council Directive of 24 November 1986 on the approximation of laws, regulations and administrative provisions of the Member States regarding the protection of animals used for experimental and other scientific purposes (86/609/EEC).

el Badwi, Samia MA, Adam SE, Shigidi MT, Hapke HJ 1998. Studies on laticiferous plants: toxic effects in goats of Calotropis procera latex given by different routes of administration. Dtsch Tierarztl Wochenschr 105: 425-427.

Girdhar G, Deval K, Mittal PK, Vasudevan P 1984. Mosquito control by Calotropis latex. Pesticides 18: 26-29.

Haque MA, Nakakita H, Ikenaga H, Sota N 2000. Development-inhibiting activity of some tropical plants against Sitophilus zeamais Motschulsky (Coleoptera: Curculionidae). J Stored Prod Res 36: 281-87.

Hillyer JF, Christensen BM 2002. Characterization of hemocytes from the yellow fever mosquito Aedes aegypti. Histochem Cell Biol 117: 431-440.

Jain SC, Sharma R, Jain R, Sharma RA 1996. Antimicrobial activity of Calotropis procera. Fitoterapia 67: 275-277.

Laemmli UK 1970. Cleavage of structural proteins during the assemble of bacteriophage $\mathrm{T}_{4}$. Nature 227: 680-88.

Larhsini M, Bousaid M, Lazrek HB, Jana M, Amarouch H 1997. Evaluation of antifungal and molluscicidal properties of extracts of Calotropis procera. Fitoterapia 68: 371-373.

Litchfield Jr JT, Wilcoxon FA 1949. A simplified method for evaluation of dose-effect experiments. J Pharm Experim Therap 96: 99-104.

Maillard M, Marston A, Hostettmann K 1993. Search for molluscicidal and larvicidal agents from plants. In M Balandrin Human Medicinal Agents from Plants, American Chemical Society, Washington D.C., 359 pp.

Miller HRP, Tainter ML 1944. Stimulation of $\mathrm{LD}_{50}$ and error by mean logarithimic probit graph paper. Proc Soc Exp Biol Med 57: 261-264.

Morsy TA, Rahem MA, Allam KA 2001. Control of Musca domestica third instar larvae by the latex of Calotropis procera (Family: Asclepiadaceae). J Egyp Soc Parasitol 31: 107-110.

Pereira LS, Gomes VM, Fernandes KVS, Sales MP, XavierFilho J 1999. Insecticidal and antifungic proteins of the latex from Manihot glaziovii Muell. Arg. Revta Bras Bot 22: 27-30.

Ramos MV, Freitas ALP, Melo VMM, Carvalho AFFU 1998. Protein content and amino acid composition in some Brazilian marine algal species. Physiol Mol Biol Plants 4: 165169.

Schagger H, Jagow GV. 1987. Tricine-sodium dodecyl sulfatepolyacrylamide gel electrophoresis for the separation of proteins in the range from 1 to $100 \mathrm{KDa}$. An Biochem 166: 368-379.

Seiber JN, Nelson CJ, Lee SM 1982. Cardenolides in the látex and leaves of seven Asclepias species and Calotropis procera. Phytochem 21: 2343-2348.

Sharma JD, Sharma P 2000. In-vitro schizonticidal screening of Calotropis procera. Fitoterapia 71: 77-79.

Shivkar YM, Kumar VL 2003. Histamine mediates the proinflammatory effect of latex of Calotropis procera in rats. Mediators Inflammation 12: 299-302.

Singhi M, Joshi V, Sharma RC, Sharma K 2004. Ovipositioning behaviour of Aedes aegypti in different concentrations of latex of Calotropis procera: studies on refractory behaviour and its sustenance across gonotrophic cycles. Dengue Bull 28: 184-188.

Wititsuwannakul D, Sakulborirug C, Wititsuwannakul R 1998. A lectin from the bark of the rubber tree (Hevea brasiliensis). Phytochemstry 47: 183-187.

Yeang HY, Siti Arija M, Arif, Faridah Yusof, Sunderasan E 2002. Allergenic proteins of natural rubber latex. Methods 27: $32-45$. 